\title{
Effect of pectin extraction method on properties of cellulose nanofibers isolated from sugar beet pulp
}

\author{
Mohammad L. Hassan $(\mathbb{D} \cdot$ Linn Berglund $(\mathbb{D} \cdot$ Wafaa S. Abou Elseoud $(1)$ \\ Enas A. Hassan (i) $\cdot$ Kristiina Oksman $(\mathbb{D})$
}

Received: 11 May 2021/Accepted: 18 September 2021 / Published online: 4 October 2021

(C) The Author(s) 2021

\begin{abstract}
In this study, the effect of pectin extraction method on the properties of cellulose nanofibers (CNFs) isolated from sugar beet pulp (SBP) was studied. Pectin was extracted by the industrially practiced method by sulfuric acid hydrolysis or by enzymatic hydrolysis using a cellulase/xylanase enzymes mixture. The CNFs were then isolated by high-pressure homogenization and investigated in terms of their chemical composition, crystallinity, size, degree of polymerization, and re-dispersion in water after freeze-drying. The mechanical properties and surface characteristics of CNF films were also studied. The results showed that fibrillation of the de-
\end{abstract}

pectinated SBP was more efficient for the acid hydrolyzed SBP. CNFs from the acid-hydrolyzed SBP had a slightly wider diameter, higher crystallinity, viscosity, and $\alpha$-cellulose content but a lower degree of polymerization than CNFs from the enzymehydrolyzed SBP. Owing to the presence of more residual hemicelluloses in the CNFs from the enzymehydrolyzed SBP, the CNFs had higher re-dispersion ability in water. CNF films from enzyme-hydrolyzed SBP displayed slightly better mechanical properties and higher water contact angle than acid-hydrolyzed CNF films.

Supplementary Information The online version contains supplementary material available at https://doi.org/10.1007/ s10570-021-04223-9.

M. L. Hassan - W. S. Abou Elseoud - E. A. Hassan Cellulose and Paper Department \& Centre of Excellence for Advanced Sciences, National Research Centre, 33 ElBuhouth Street, Dokki, Giza 12622, Egypt

L. Berglund · K. Oksman $(\square)$

Division of Materials Science, Department of Engineering

Sciences and Mathematics, Luleå University of

Technology, 97187 Luleå, Sweden

e-mail: kristiina.oksman@1tu.se

K. Oksman

Department of Mechanical and Industrial Engineering, University of Toronto, 5 King's College Road, Toronto, ON M5S 3G8, Canada 


\section{Graphic abstract}

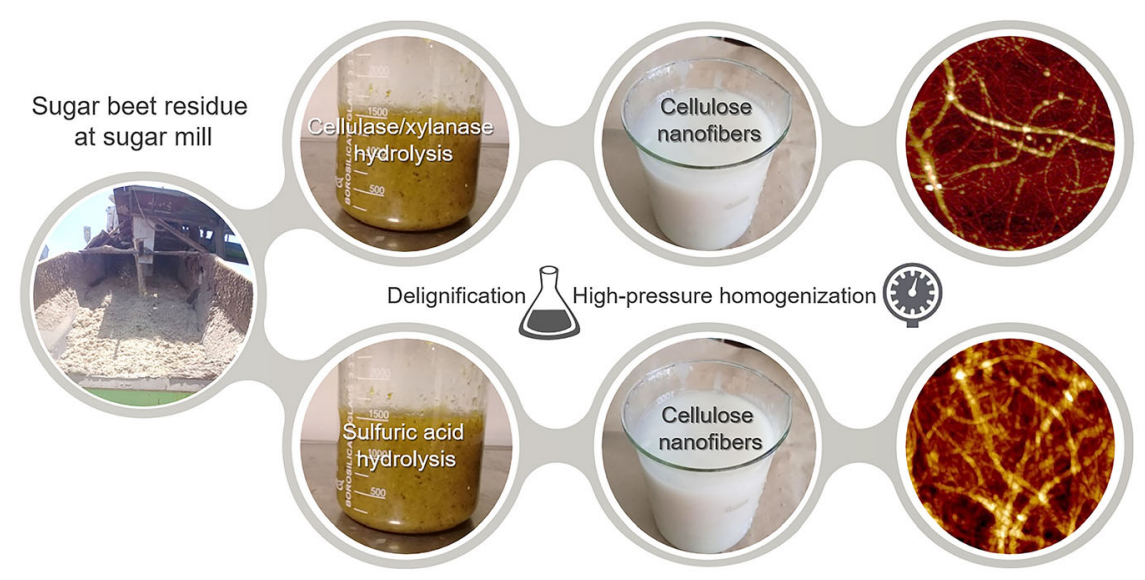

Keywords Sugar beet pulp - Cellulose nanofibers . Acid hydrolysis · Enzymatic hydrolysis · Cellulases . Xylanases

\section{Introduction}

Sugar beet pulp (SBP) is a common agricultural residue in different areas of the world as $20 \%$ of the world production of sugar comes from sugar beets (Stevanato et al. 2019). Sugar beets are cultivated in Europe, North and South America, Asia, and a few countries in Africa where temperate climates exist. The top producer is the Russian Federation, followed by France, the United States, Germany, and Turkey. In Africa, Egypt is the leading country in sugar beet cultivation and the 8th top producer in the world. After sugar extraction, SBP residue is rich in some carbohydrate polymers and other minor components. The chemical composition of SBP is approximately $21-30 \%$ pectin, $22-25 \%$ cellulose, $22-25 \%$ hemicelluloses, $5-10 \%$ protein, lignin $<5 \%$, phenolics $<1 \%$, and ash $<1 \%$ (Fishman et al. 2011; Li et al. 2014).

Indeed, the cell wall structure of sugar beet is quite unique and different from those of agricultural residues such bagasse, rice straw, etc. Most of the tissue in sugar beet is parenchymal, which is separated by vascular tissue (Dinand et al. 1999). The parenchymal tissue is characterized by only primary wall of very thin thickness (as low as $0.1 \mu \mathrm{m}$ ). The intervascular parenchyma consists of arrays of ovoid cells having diameters ranging from 50 to $200 \mu \mathrm{m}$. Other parenchymal cells also exist in the vascular tissue, so called phloem parenchyma, and characterized by very thin wall with an elongated structure, with diameter of $0.4 \mu \mathrm{m}$ and lengths of around $100 \mu \mathrm{m}$. Similar to the primary walls in different plants, the thin walls of the different parenchymal cells contain loosely organized cellulose microfibrils embedded in a matrix of hemicelluloses and pectin. The cellulose microfibrils are either isolated with about $3 \mathrm{~nm}$ diameter or organized in thin bundles with a limited number of parallel microfibrils (Dinand et al. 1999). This loose microfibrillar organization in the matrix facilitates separation of cellulose microfibrils by mechanical action.

Regarding hemicelluloses in SBP, they contain both xylan and xyloglucan polymers (Kato and Kobayashi 2000). Xylan part in SBP consists mainly of a linear $(\beta 1 \rightarrow 4)$-linked D-xylopyranosyl backbone ( $\sim 89 \%$ of total xylan structure) with side chains at the $O-2$ and $O-3$ positions, consisting of glucose, arabinose, glucouronic acid, galactose, and rhamnose sugars. On the other hand, xyloglucan consists of ( $\beta$ $1 \rightarrow 4$ )-linked D-glucosyl units substituted at the $O-6$ positions with single $\alpha$-D-xylopyranosyl, $\beta$-D-galactopyranosyl-( $1 \rightarrow 2)$ - $\alpha$ - D-xylopyranosyl, and $(\alpha 1 \rightarrow 2)$ - 
L-fucopyranosyl-( $\beta \quad 1 \rightarrow 2)$-D-galactopyranosyl- $(\alpha$ $1 \rightarrow 2$ )-D-xylopyranosyl residues.

Pectin in sugar beet has rather complicated structure. It consists of different structural elements known as homogalacturonan (HG) and rhamnogalacturonan with two structures so called RG I and RG II structures. These elements are linked to each other via different suggested models (Vincken et al. 2003; Schols et al. 2009). The HG elements are linear chains of $(\alpha 1 \rightarrow 4)$-linked D-galacturonic acid residues which could be acetyl-esterified at $O-2$ and/or $O-3$ and methyl-esterified at $O-6$ (Combo et al. 2013). The RG I elements consist of alternating rhamnose and galacturonic acid units. From the rhamnose units, linear $(\beta 1 \rightarrow 4)$-linked galactan and arabinan are branched. The branched arabinan consists of $(\alpha 1 \rightarrow 5)$-linked backbones with $(\alpha 1 \rightarrow 2)$ and/or $(\alpha 1 \rightarrow 3)$-arabino furanosyl substitutions, while RG II elements, which exist to much less extent in sugar beet than RG I, consist of galacturonic acid with side chains of different sugars (galactose, arabinose, rhamnose, and xylose). Protein and ferulic acid residues are linked to the arabinan and galactan side chains of the RG I elements (Levigne et al. 2002; Siew and Williams 2008); only very few plants have ferulic acid residues in the RG I elements, and sugar beet is one of them.

In such unique complicated cell wall structure of SBP, xylan and xyloglucan of hemicelluloses are connected to pectin through ester bonds between their hydroxyl groups and the galacturonic acid groups of pectin (Fischer et al. 1994). Cellulose microfibrils on the other hand are linked to pectin in the cell wall in similar manner to that with hemicelluloses (Zykwinska et al. 2005, 2007).

For efficient use of SBP residue, industrially valuable polymers such as pectin and cellulose should be isolated using optimized protocols. Pectin extraction from the cell wall of sugar beet requires breaking the bonds between cellulose, hemicelluloses, and pectin. Although hydrolysis using mineral acids is a common industrial method for pectin extraction, other methods, such as enzymatic hydrolysis, have also been studied (Zykwinska et al. 2008; Concha et al. 2013; Babbar et al. 2016; Pacheco et al. 2019; Abou-Elseoud et al. 2021). In addition to being a more environmentally sound approach than mineral acid hydrolysis, enzymatic hydrolysis was also found to be effective in terms of pectin yield in these previous studies. After pectin extraction, the de-pectinated SBP becomes enriched with cellulose fibers, which can be used to isolate nanocellulose (cellulose nanofibers and nanocrystals) known to have interesting mechanical, optical, and physical properties, making them applicable in several areas (Thomas et al. 2018). The isolation of CNFs from de-pectinated SBP has been studied in past years. In these studies, the main protocol was to first remove pectin from SBP by alkali treatment, then remove lignin by bleaching, and finally isolate CNFs from the purified pulp using highpressure homogenizers (Leitner et al. 2007; Li et al. 2014; Pinkl et al. 2017). The use of mixtures of enzymes (pectinases, hemicellulases, amylase, and endo-glucanase) to purify the cellulose fraction from residual pectin after alkali treatment and bleaching of SBP was also studied. The purified pulp was then subjected to high-pressure homogenization to produce CNFs (Holland et al. 2019; Perzon et al. 2020). In a slightly different protocol to isolate CNFs, SBP was first treated with hot nitric acid solution three times, alkali treated three times, bleached with sodium chlorite/acetic acid, treated with ultrasonication, and finally subjected to high-pressure homogenization (Agoda-Tandjawa et al. 2010). CNFs from SBP were also isolated without the removal of pectin or other polysaccharides; only a bleaching step with sodium chlorite/acetic acid was carried out, and the CNFs were isolated by high-pressure homogenization (Hietala et al. 2017); the isolated nanofibers contained significant amounts of pectin, which gave them high re-dispersion properties after drying. CNFs from SBP were also isolated without chemical treatment by direct grinding using an ultrafine grinder followed by high-pressure homogenization (Vartiainen et al. 2015). Using a different approach, SBP was subjected to steam explosion pretreatment before bleaching and ultrasonic treatment to obtain CNFs (Yang et al. 2018).

Despite successful isolation of CNFs from SBP in the above-mentioned studies, full use of the major components of SBP in industry, e.g., pectin and cellulose, is necessary for economic reasons to expand the traditional use of SBP for animal feed alone. Therefore, optimized isolation of pectin before using the cellulose fraction is mandatory. In addition, because different methods can be used for pectin extraction, the effect of these methods on the properties of isolated CNFs needs to be studied. The different methods of pectin extraction of course affect its 
properties; for example, pectin isolated from sugar beet pulp using cellulase/xylanase enzymes mixture was found to have lower galacturonic acid than that produced using sulfuric acid hydrolysis but pectin isolated by the enzymes mixture was higher in neutral sugars content, degree of esterification, and molecular weight (Abou-Elseoud et al. 2021).

The aim of the current work was to study the differences in properties of CNFs isolated from SBP residue by first optimizing the pectin isolation using the conventional industrially practiced sulfuric acid hydrolysis or enzymatic treatment with a mixture of xylanase/cellulase enzymes, and then using the depectinated SBP to isolate the CNFs. The study also focused on the progression of fibrillation using acidand enzymatic-hydrolyzed SBP, the re-dispersion of the dried nanofibers, and the properties of CNF films prepared by casting.

\section{Experimental}

\section{Raw material and reagents}

SBP was kindly supplied by Alnubariah Company for Sugar, Alexandria, Egypt. The chemical composition of the SBP regarding $\alpha$-cellulose, pentosans, lignin, and ash content was determined according to standard methods of chemical analyses (Browning 1967); galacturonic acid content (as a measure for pectic substance) was determined according to the previously published method using $m$-hydroxybiphenyl reagent (Meseguer et al. 1998). Protein content was determined from the nitrogen content analysis by the Kjeldahl method (Sàez-Plaza et al. 2013), where protein content $\%=\mathrm{N} \% \times 6.25$. Cellulase from Trichoderma longibrachiatum ( $\beta$-glucosidase powder, $\geq 1.0 \mathrm{unit} / \mathrm{mg}$ ) and xylanase (Purified endo- $\beta 1 \rightarrow 4$ )xylanase powder, $\geq 2500$ units/g) from Thermomyces lanuginosus were purchased from Sigma Aldrich Sweden AB (Stockholm, Sweden) and used as received. Regarding activity of the enzymes, one unit of cellulase enzyme liberates $1.0 \mu$ mole of glucose from cellulose in $1 \mathrm{~h}$ at $\mathrm{pH} 5.0$ at $37{ }^{\circ} \mathrm{C}$ after $2 \mathrm{~h}$ incubation time, while one unit of xylanase liberates 1 $\mu$ mole of reducing sugar measured as xylose equivalents from xylan per min at $\mathrm{pH} 4.5$ at $30{ }^{\circ} \mathrm{C}$.

Sodium chlorite (technical grade $80 \%$ ), glacial acetic acid, sulfuric acid, sodium thiosulfate, potassium bromide, potassium bromate, hydrochloric acid, acetic acid, citric acid, and sodium hydroxide were of analytical grade. They were purchased from Fisher Scientific U.K. Ldt (Loughborough, UK) and used as received.

Extraction of pectin by enzymatic hydrolysis

Extraction of pectin from SBP using cellulase and xylanase mixture was carried out as previously published by Abou-Elseoud et al. (2021). A mixture of xylanase and cellulase in a ratio of 1:1.5 was prepared in citrate buffer at $25^{\circ} \mathrm{C}$. SBP, previously ground to pass through a 40-mesh screen, was added to the enzyme mixture at a liquor ratio of 1:15 (SBP to enzyme mixture) at $50{ }^{\circ} \mathrm{C}$ under shaking at $150 \mathrm{rpm}$ for $4 \mathrm{~h}$. The enzymes were then inactivated by heating at $100{ }^{\circ} \mathrm{C}$ for $5 \mathrm{~min}$. The residue (de-pectinated SBP) was separated from the soluble compounds by vacuum filtration and washed with distilled water. The depectinated SBP yield was calculated as follows Eq. 1:

$$
\begin{aligned}
& \text { De-pectinated SBP yield }(\%) \\
& =(\text { dry weight of SBP after extraction/ } \\
& \quad \text { dry weight of SBP before extraction }) \times 100 \text {. }
\end{aligned}
$$

The filtrate was centrifuged at $10,000 \mathrm{rpm}$ for $10 \mathrm{~min}$ to remove fine particles (fines), and pectin was precipitated by the addition of ethanol at volume ratio of 3:1 ethanol to filtrate. After $2 \mathrm{~h}$, the precipitated pectin was centrifuged at $10,000 \mathrm{rpm}$ for $20 \mathrm{~min}$, washed with $70 \%$ ethanol, centrifuged again, and dried at $40{ }^{\circ} \mathrm{C}$ for $48 \mathrm{~h}$. The pectin yield was calculated as follows Eq. 2:

Pectin yield $(\%)$

$=($ dry weight of pectin/dry weight of SBP $) \times 100$.

Extraction of pectin by acid hydrolysis was carried out as previously published by Abou-Elseoud et al. (2021). SBP was suspended in water at a liquor ratio of 1:15 and acidified to $\mathrm{pH} 1$ with sulfuric acid. It was then heated for $2 \mathrm{~h}$ at $85^{\circ} \mathrm{C}$ under mechanical stirring. The residue was then separated from the soluble compounds by vacuum filtration and washed with distilled water. 
Isolation of cellulose nanofibers

After pectin extraction, the de-pectinated SBP samples were washed with water and then treated with diluted sodium hydroxide (4\% based on de-pectinated SBP weight) at $25{ }^{\circ} \mathrm{C}$ under mechanical stirring for $1 \mathrm{~h}$ to remove residual solubilized pectin that was not removed by washing. Then, the mixture was filtered, and the produced pulp was washed with water until reaching neutral $\mathrm{pH}$. The pulp was finally bleached with a sodium chlorite/acetic acid mixture at $80{ }^{\circ} \mathrm{C}$ for $1 \mathrm{~h}$ (Wise et al. 1946). To isolate the CNFs, the purified pulp, at $2 \mathrm{wt} \%$ consistency, was mixed for $15 \mathrm{~min}$ in a Silverson L4RT shear mixer (Silverson Machines Ltd., Chesham, UK) followed by highpressure homogenization using a two-chamber APV2000 high-pressure homogenizer (SPX, Soeborg, Denmark). The pressure was maintained at 40 bar in one chamber and at 400 bar in the other chamber. The number of passes through the homogenizer varied from one to five times depending on the progression of fibrillation. The progression of the fibrillation was followed by measuring the viscosity at different passes/time through the homogenizer using a tuningfork vibration viscometer Vibro Viscometer SV-10 (A\&D Company Limited, Tokyo, Japan). The progression of fibrillation was also followed by optical microscopy using a polarizing microscope (Nikon Eclipse V100N POL, Tokyo, Japan) and the imaging software NIS-Elements D 4.30.

\section{Characterization of isolated CNFs}

The chemical composition of isolated CNFs was determined according to standard methods of analyses of $\alpha$-cellulose, hemicelluloses (as pentosans), lignin, and ash content (Browning 1967). Galacturonic acid content was determined according to the previously published method using $m$-hydroxybiphenyl reagent (Meseguer et al. 1998). Protein content was determined from the nitrogen content analysis by the Kjeldahl method (Sàez-Plaza et al. 2013).

The microstructure of the SBP before and after pectin extraction was investigated using an FEI Quanta 200 scanning electron microscope (SEM; FEI Company, Eindhoven, The Netherlands). SBP samples were coated with gold prior to investigation using a sputtering coating system (Edwards Vacuum Engineering, Sussex, UK).
The microstructure of the isolated CNFs was studied using a high-resolution transmission electron microscope (TEM) (JEM-2100, JEOL, Tokyo, Japan). A drop of highly diluted CNF suspension $(\sim 0.02$ $\mathrm{wt} \%$ ) was placed on a copper grid bearing a carbon film. After the sample was dried, phosphotungstic acid staining was applied and left to dry before the test. Staining was applied to improve contrast during imaging.

Atomic force microscopy (AFM) was also used to measure the size of the CNFs. Suspension with a concentration of $0.01 \mathrm{wt} \%$ was dropped onto freshly cleaved mica for scanning with a Veeco Multimode Scanning Probe (Santa Barbara, CA, USA) in tapping mode using a tip model TESPA [antimony (n)-doped Si] (Bruker, Camarillo, CA, USA). Height scans were used to measure the width in air at $22{ }^{\circ} \mathrm{C}$ using Nanoscope $\mathrm{V}$ software. The average values and standard deviations presented were based on 60 separate measurements. CNF suspensions $(\sim 2$ $\mathrm{wt} \%$ ) isolated from both the enzyme- and acidhydrolyzed SBP were freeze-dried as follows: The suspensions were stored in a freezer at a temperature of approximately $-20{ }^{\circ} \mathrm{C}$ for at least $24 \mathrm{~h}$ prior to freeze-drying, which was conducted for $48 \mathrm{~h}$ using a freeze dryer (Alpha 2-4 LD Plus, CHRIST GmbH, Osterode am Harz, Germany) at a temperature of $-40{ }^{\circ} \mathrm{C}$ and a vacuum of 0.12 mbar.

For the testing of re-dispersion in water, $0.1 \mathrm{~g}$ of the freeze-dried CNFs was dispersed in $100 \mathrm{~mL}$ of deionized water and stirred with a magnetic stirrer for $10 \mathrm{~min}$ at $300 \mathrm{rpm}$. Last, ultrasonic treatment was applied for $1 \mathrm{~min}$ using a 400 Hielscher ultrasonic processor (Hielscher Ultrasonics $\mathrm{GmbH}$, Teltow, Germany). A 1-cm-diameter probe was used at an amplitude of $75 \%$; the beaker was kept in ice water to avoid water evaporation. Light transmittance was measured immediately after ultrasonic treatment using a UV-visible spectrophotometer (Jenway 7205, Staffordshire, England) at 400-800 nm. The ultrasonic treatment was repeated at $1 \mathrm{~min}$ intervals, and light transmittance was measured until no noticeable change occurred. The total ultrasonic time used was $6 \mathrm{~min}$ for all samples. The re-dispersed nanofibers were analyzed using optical microscopy directly after re-dispersion. In addition, few drops of the methylene blue dye solution $(0.1 \mathrm{~g}$ in $50 \mathrm{ml}$ of distilled water) were added to the CNF suspensions after the ultrasonic treatment of the freeze dried nanofibers. The mixture 
was left for 15 min and excess dye was removed by repeated centrifugation and washing with distilled water before imaging. The images were recorded using Optika-290 series microscope (OPTIKA, Ponteranica, Italy) for a drop of the suspension at $25^{\circ} \mathrm{C}$.

The X-ray diffraction (XRD) patterns of CNFs were recorded using an Empyrean X-ray diffractometer (PANalytical, Netherlands). The counting time was $150 \mathrm{~s}$, current was $35 \mathrm{~mA}$, and step size was $0.053^{\circ}$. The crystallinity index was calculated from the XRD patterns according to the following Eq. 3 (Sidiras et al. 1990):

$\mathrm{CrI}=\left(\mathrm{I}_{002}-\mathrm{I}_{\mathrm{am}}\right) / \mathrm{I}_{002}$,

where $\mathrm{I}_{002}$ is the intensity of the diffraction profile at the position of the 002 peak $\left(2 \theta=22.7^{\circ}\right)$ and $\mathrm{I}_{\mathrm{am}}$ is the intensity at approximately $2 \theta=18^{\circ}$. The degree of polymerization (DP) of the CNFs was determined using the bis(ethylenediamine)copper(II) hydroxide solution method. Approximately $0.1 \mathrm{~g}$ was used in the test (Browning 1967).

\section{Characterization of CNF films}

CNF films were prepared by casting CNF suspensions in a 9-cm-diameter Teflon petri dish. The suspensions were dried at $40{ }^{\circ} \mathrm{C}$ for $18 \mathrm{~h}$ in an oven with circulating air. The produced films were conditioned at $50 \%$ relative humidity for $48 \mathrm{~h}$ at $25^{\circ} \mathrm{C}$ before testing.

The wettability of the CNF films was assessed by water contact angle measurements using an EASYDROP measuring system, drop shape analysis control (DSA1), and evaluation software (Krüss $\mathrm{GmbH}$, Hamburg, Germany). A $4 \mathrm{~mL}$ water drop was released onto the sample surface, and its contact angle was measured by the sessile drop technique. The reported values are the average of six measurements for each sample.

The topographical features of the CNF films were studied using the same AFM setup described above, and the root-mean-square roughness was measured from the $15 \mu \mathrm{m} \times 15 \mu \mathrm{m}$ height scans. This was carried out to compare the topographical features of the surfaces of the films and their potential effect on the contact angle measurement. The corresponding amplitude (deflection) images were also collected. The reported roughness values are the average of seven separate measurements from 15 to $15 \mu \mathrm{m}$ height scans at different areas of the films.

The mechanical properties were measured using a Lloyd instrument (LR10 K; Lloyd Instruments, Fareham, UK) with a $1 \mathrm{kN}$ load cell at $25^{\circ} \mathrm{C}$ using a crosshead speed of $2 \mathrm{~mm} / \mathrm{min}$. The sample width and length were 10 and $60 \mathrm{~mm}$, respectively, and the distance between the grips was $20 \mathrm{~mm}$. Five specimens from each sample were measured, and the results were averaged.

\section{Results and discussion}

For effective use of the SBP residue, its pectin should be extracted first under optimized conditions. Pectin is an important food additive, and its isolation from the sugar beet should be carried out carefully to obtain the highest possible yield while maintaining its functional properties such as emulsification and gelling. After pectin extraction, the residual pulp has high cellulose content, which can be used to produce nanofibers with relatively low energy consumption. In the current work, pectin was extracted by sulfuric acid hydrolysis as it is practiced industrially or by enzymatic hydrolysis using a mixture of xylanase and cellulase enzymes; the conditions of pectin extraction by both methods were optimized in a previous publication to get highest pectin yield (Abou-Elseoud et al. 2021); the pulp residues after pectin extraction were used to isolate CNFs. In case of sulfuric acid extraction, the de-pectinated SBP residue was $43.1 \%$, which was reached under extraction conditions of $85{ }^{\circ} \mathrm{C}$ for $2 \mathrm{~h}$ at pH 2. With enzymatic hydrolysis, the de-pectinated SBP residue was $61.4 \%$, which was reached using a 1:1.5 xylanase to cellulase enzymes mixture. The lower residual de-pectinated SBP with acidic extraction could have been owing to hydrolysis of more polysaccharides into water-soluble products than was the case when using enzymes.

Figure 1 shows SBP before and after pectin extraction. As shown in Fig. 1a-c, after pectin extraction from SBP by the acid or enzymes hydrolysis, most of the parenchymal tissues between and in the vascular bundles collapsed, and thus the characteristic vascular fibers bundles became clearly visible. These vascular bundles de-folded at longer reaction times and under mechanical stirring. As Fig. 1d shows, the bundles have few microns diameter but 

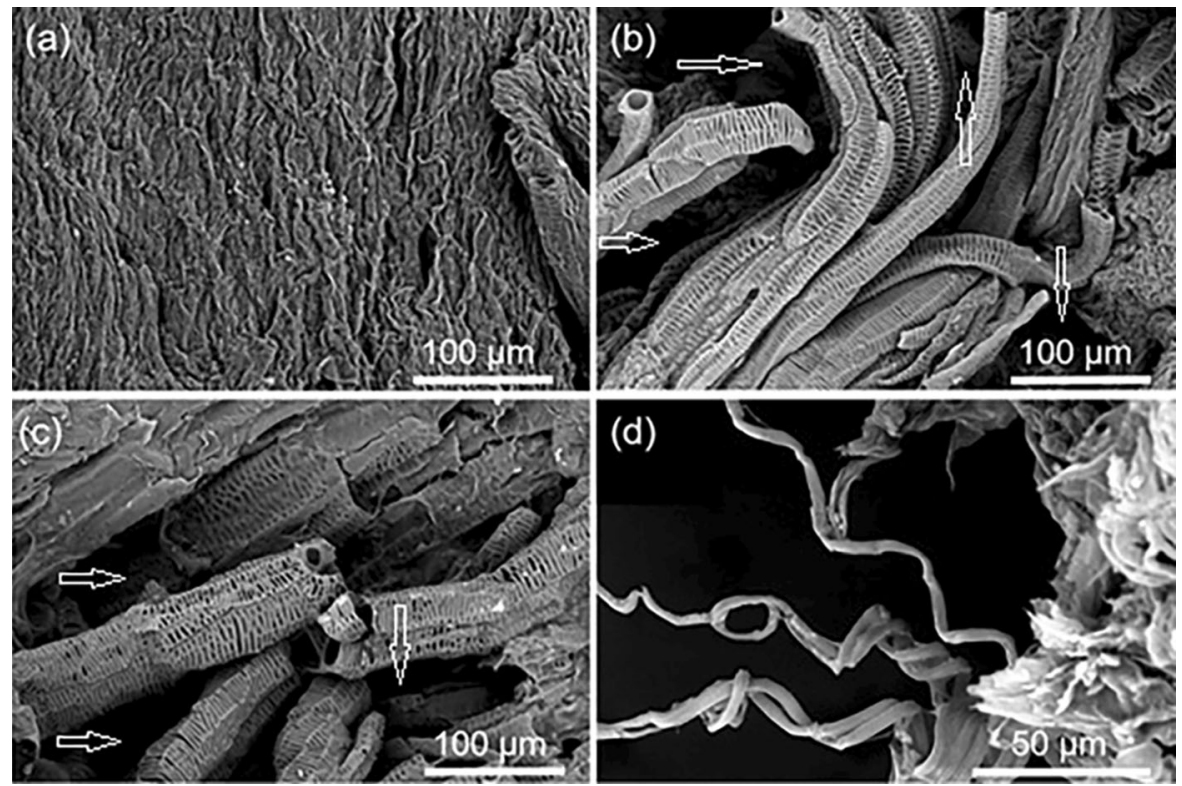

Fig. 1 SEM images of SBP a before pectin extraction, b after pectin extraction with sulfuric acid at $85{ }^{\circ} \mathrm{C}$ for $2 \mathrm{~h}$, $\mathbf{c}$ after pectin extraction with a 1:1.5 xylanase/cellulase enzyme mixture, and $\mathbf{d}$ after pectin extraction with sulfuric acid at $85{ }^{\circ} \mathrm{C}$ for $4 \mathrm{~h}$

hundred microns in length. The bundles contain cellulose microfibrils embedded in residual hemicelluloses and pectin. It is noted from the images that the vascular bundles obtained after pectin extraction by enzyme hydrolysis have more residual parenchymal tissue at their surfaces. Indeed, after extraction pectin from the parenchymal tissue, the remained very thin cell wall contains the cellulose microfibrils and can easily be broken by mechanical action liberating the microfibrils or microfibrils bundles (Dinand et al. 1999).

\section{Fibrillation of CNFs}

The fibrillation progression of CNFs from the depectinated SBP by acid or enzymatic hydrolysis using high-pressure homogenization was measured using viscosity measurements and optical microscopy. Previous studies have shown that increased viscosity is a good measure of the progression of fibrillation as viscosity increases with increasing fibrillation (Berglund et al. 2020; Hassan et al. 2018). This increase in viscosity is due to an increase in the surface area and the high-water binding capacity of the isolated nanofibers. As shown in Fig. 2, the viscosity of the acid hydrolyzed SBP suspension increased very rapidly during the first pass of homogenization,

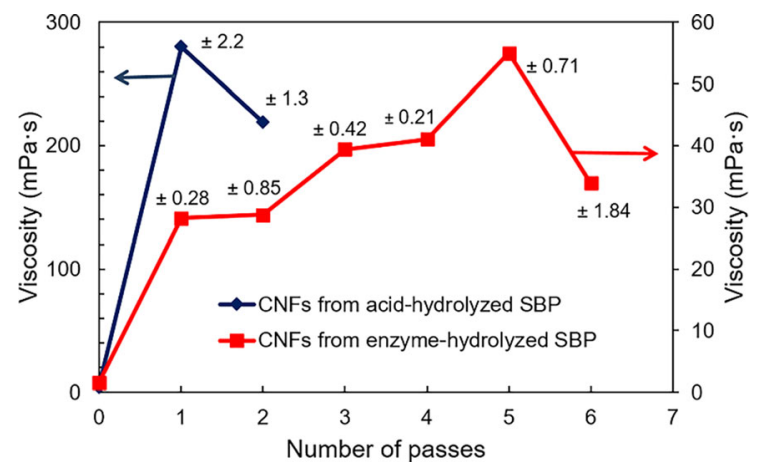

Fig. 2 Effect of number of passes through the high-pressure homogenizer on viscosity of isolated nanofibers

followed by a decrease; the maximum viscosity was $280 \mathrm{mPa} \cdot \mathrm{s}$ after the first pass. The temperature increased from 25.5 to $43{ }^{\circ} \mathrm{C}$ after two passes, which could also cause a decrease in the measured viscosity. The viscosity of the enzyme hydrolyzed SBP residue increased to a much less extent and reached a maximum after five passes; the maximum viscosity was $55 \mathrm{mPa} \cdot \mathrm{s}$ and the temperature reached $43{ }^{\circ} \mathrm{C}$. These results indicate faster isolation of CNFs when using the acid hydrolyzed SBP residue.

These results were also confirmed by optical microscopy images taken during the high-pressure homogenization. These images are shown in Figs. 3 

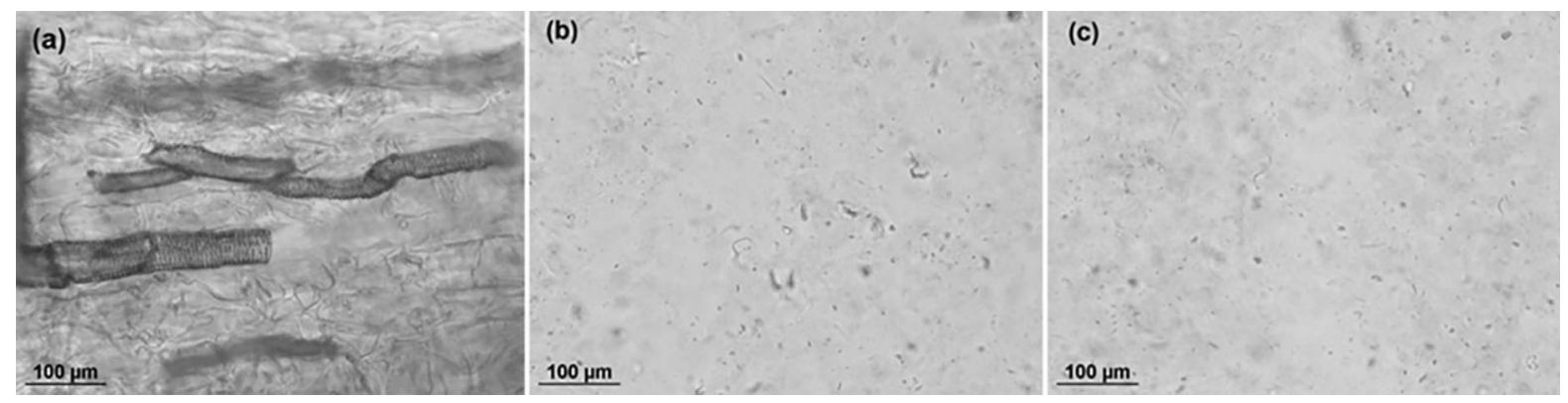

Fig. 3 Optical microscopy images of acid-hydrolyzed SBP after passage through the high-pressure homogenizer a zero, b one, and c two times
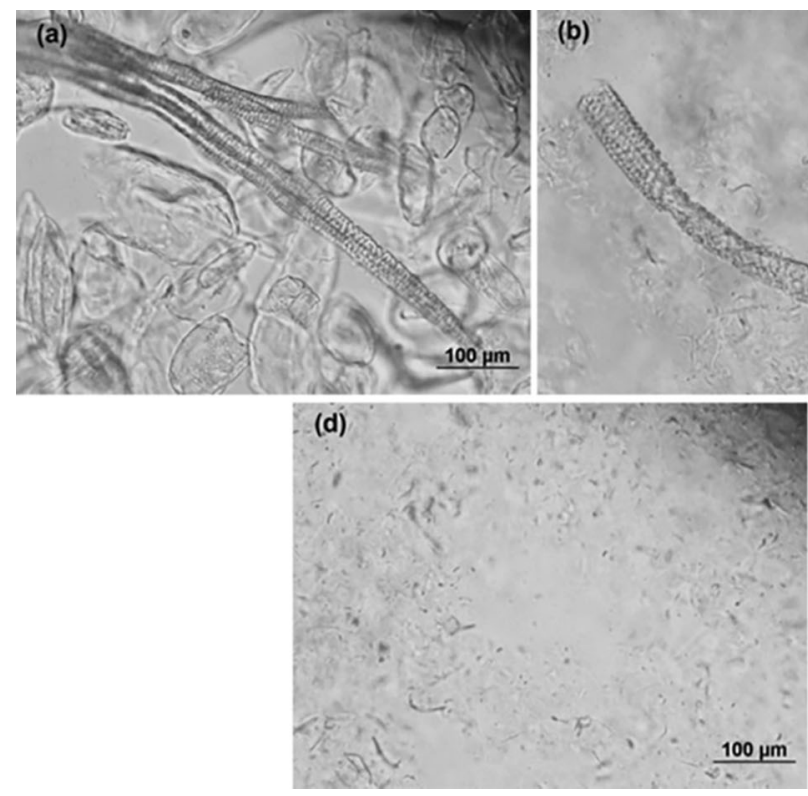

(b)

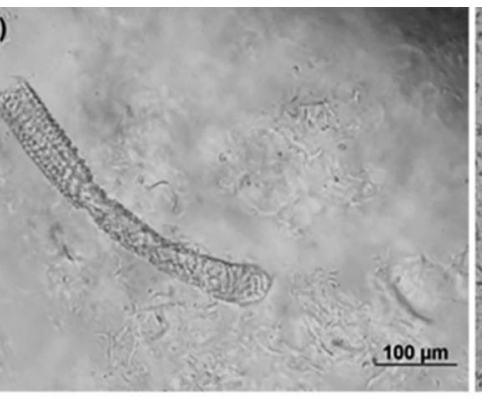

(e)
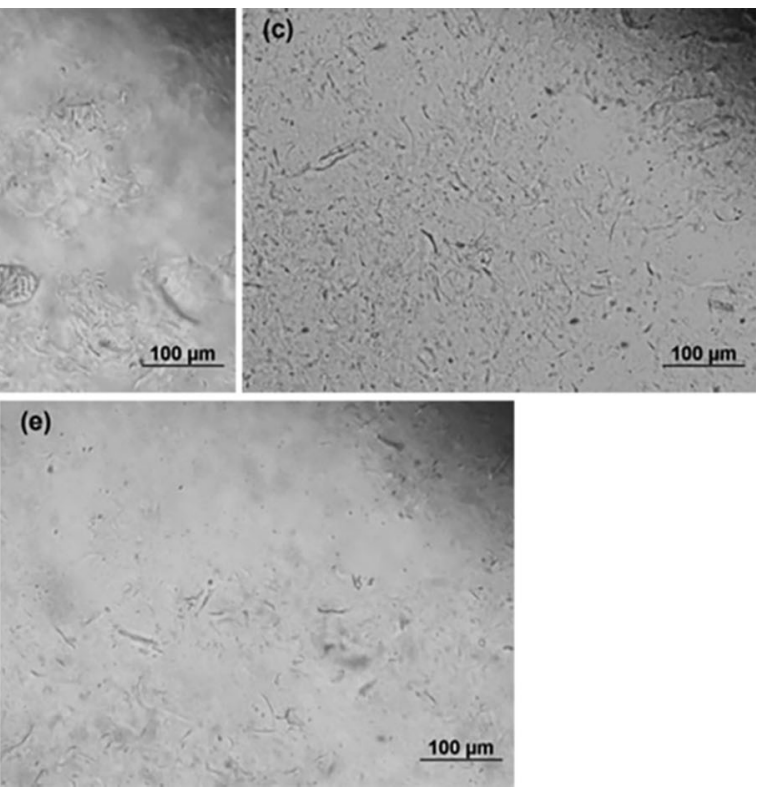

Fig. 4 Optical microscopy images of enzyme-hydrolyzed SBP after passage through high-pressure homogenizer a zero, $\mathbf{b}$ one, $\mathbf{c}$ three, d five, and e six times

and 4 for the acid-hydrolyzed and enzyme-hydrolyzed SBP, respectively. The micrographs show faster disappearance of the micro-sized fibers bundles and also the non-fibrous very thin-walled flatten parenchyma cells in the ground of the image (Fig. 3a) of the acid-hydrolyzed SBP than with the enzymatic hydrolysis (Fig. 4a). Upon high-pressure homogenization, the nonfibrous parenchymal cells disappeared, as well as the micro-sized xylem, which disintegrated into nano-sized fibrils and became non-visible under the magnification of the optical microscope.

The difference in the progression of fibrillation and viscosity values could be interpreted from chemical analyses of SBP and the nanofibers as seen in Table 1.
SBP contains mixture of different polymers mainly pectin, cellulose, and hemicelluloses exist in very complex structure and connected together via different kinds of bonds. Hemicelluloses in SBP consist mainly of xylan ( $\sim 89 \%$ of which are xylose backbone) and xyloglucan polymers (Kato and Kobayashi 2000) as mentioned in the Introduction. These hemicelluloses are chemically linked to pectin through ester bonds with pectin (Fischer et al. 1994). Cellulose microfibrils in SBP are linked to pectin in the cell wall in similar way to that of hemicelluloses (Zykwinska et al. 2005, 2007). Evidence also exists regarding linkages between pectin, hemicelluloses, and cellulose via hydrogen and chemical bonding (Fry 1986; Iiyama 
Table 1 Chemical composition of sugar beet pulp (SBP) and the isolated CNFs

\begin{tabular}{llrrrrr}
\hline Materials & $\alpha$-Cellulose & Pentosans $(\%)$ & $\begin{array}{l}\text { Galacturonic acid } \\
(\%)\end{array}$ & Lignin $(\%)$ & $\begin{array}{l}\text { Protein content } \\
(\%)\end{array}$ & Ash $(\%)$ \\
\hline SBP & $38.02 \pm 2.24$ & $18.20 \pm 2.12$ & $19.40 \pm 1.27$ & $3.85 \pm 0.21$ & $10.13 \pm 0.93$ & $2.77 \pm 0.42$ \\
CNF acid hydrolysis & $87.80 \pm 3.60$ & $6.96 \pm 0.79$ & $2.44 \pm 0.47$ & $0.45 \pm 0.16$ & $0.31 \pm 0.01$ & $1.10 \pm 0.08$ \\
$\begin{array}{l}\text { CNF enzymes } \\
\text { hydrolysis }\end{array}$ & $76.90 \pm 1.60$ & $17.09 \pm 1.39$ & $2.21 \pm 0.19$ & $0.52 \pm 0.5$ & $0.25 \pm 0.02$ & $1.21 \pm 0.05$ \\
\hline
\end{tabular}

et al. 1994). Therefore, extraction any of these components depends on cleaving the links between these polysaccharides. In addition to the aforementioned polymers in SBP, considerable amount of protein exists in SBP which is linked to pectin (Levigne et al. 2002; Siew and Williams 2008).

As shown in Table 1, after pectin extraction by acid or enzymatic hydrolysis followed by bleaching of SBP, higher $\alpha$-cellulose content $(\sim 88 \%$ ) was found with the acid-hydrolyzed SBP than with the enzymehydrolyzed SBP $(\sim 77 \%)$. This means that with the acid hydrolyzed SBP, removal of most of the hemicelluloses and pectin, which are chemically linked to cellulose fibers (Fry 1986; Iiyama et al. 1994) took place resulting in easier fibrillation and much faster increase in viscosity. The hemicelluloses content (estimated as pentosans) was $\sim 7.0 \%$ and $17 \%$ for CNFs from the acid- and enzyme-hydrolyzed SBP, respectively. In fact, majority of hemicelluloses (xylans and xyloglucan) in sugar beet pulp are pentoses as previous studies proved (Kato and Kobayashi 2000). That's why pentosans were taken as indication for hemicelluloses. Other hexoses also exist in xylan and xyloglucan structures such as glucose (which also the cellulose monomer) and galactose. It is important to mention that pectic substance in SBP also contains pentose sugars (arabinose). Residual pectic substance in the nanofibers, estimated as galacturonic acid, was $2.44 \%$ and $2.21 \%$ in case of acid- and enzymehydrolyzed CNFs, respectively, compared to $19 \%$ in the SBP. It should be also noted that pectic substance in SBP consists of galacturonic backbone, in addition to branches of galactan and arabinan from the rhamnogalacturonan units (Schols et al. 2009).

The higher viscosity at the end of fibrillation for the acid-hydrolyzed SBP than for the enzyme-hydrolyzed SBP could be attributed to the higher cellulose content of the former, i.e., more nanofibers were liberated in the water suspension by high-pressure homogenization. In fact, hemicelluloses and pectin in SBP have low molecular weight and viscosity, and thus their presence in the isolated nanofibers is not expected to considerably affect the viscosity of the CNF suspension. The presence of residual pectin with nanofibers isolated from SBP was reported in a previous publication, despite the strong alkali extraction used in these previous studies (Perzon et al. 2020). Owing to the bleaching of SBP, traces of lignin were detected in both types of nanofibers $(0.5 \%)$. The DP of cellulose was 639 and 894 for nanofibers isolated from the acidand enzyme-hydrolyzed SBP, respectively. The lower DP of the nanofibers from the acid hydrolyzed SBP was more likely owing to more degradation by the action of the acid during pectin extraction than that in case of using the enzymes. It should be pointed out here that cellulases can definitely cause degradation of cellulose but the extent of their effect depends on the conditions used in the treatment, especially their dose and also length of duration. The conditions used in the current work was based on our previous study on using the cellulase/xylanase mixture for optimizing pectin extraction where the minimum possible amount that could give good yield of pectin was used (AbouElseoud et al. 2021).

\section{Microstructure of isolated CNFs}

Regarding the dimensions of the isolated nanofibers, TEM images showed that the diameters of the nanofibers isolated from both types of SBP residue were very homogenous. The diameters were 6-10 nm and $3-5 \mathrm{~nm}$ for nanofibers isolated from acid- and enzyme-hydrolyzed SBP, respectively (Fig. 5a and b, respectively). This means that elementary cellulose fibrils could be easily isolated from both types of SBP residue using high-pressure homogenization after one 

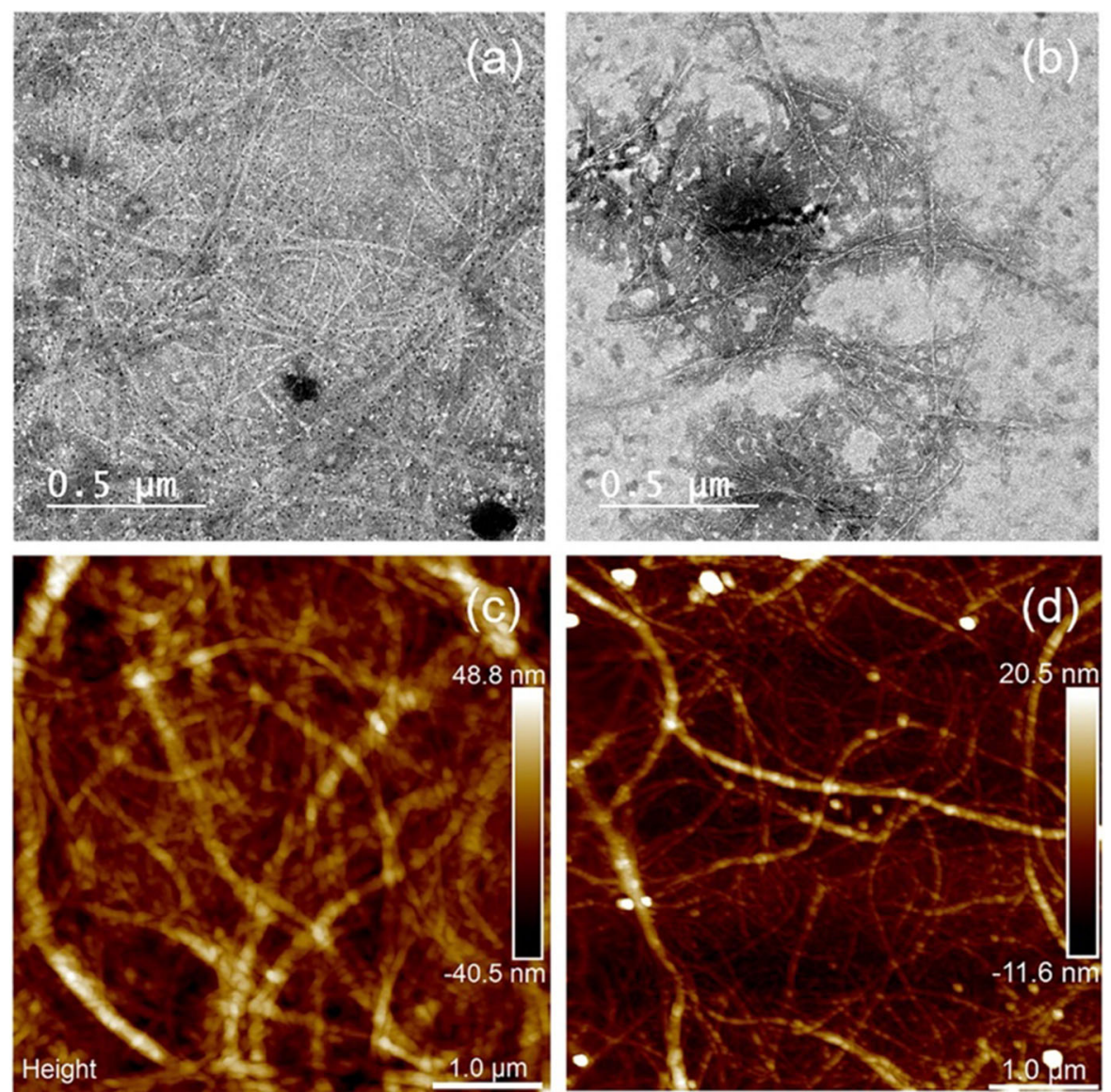

Fig. 5 TEM images of CNFs isolated from $\mathbf{a}$ acid-hydrolyzed SBP and $\mathbf{b}$ enzyme-hydrolyzed SBP. AFM images in height mode of CNFs isolated from $\mathbf{c}$ acid-hydrolyzed SBP and $\mathbf{d}$ enzyme-hydrolyzed SBP

and five passes through the homogenizer for acid- and enzyme-hydrolyzed SBP, respectively. The length of the nanofibers was several microns for both types of SBP residue. AFM images confirmed the trend of the diameter of isolated nanofibers for both types of SBP residue; the measured height were $10 \pm 5 \mathrm{~nm}$ and $7 \pm 4 \mathrm{~nm}$ for the acid- and enzyme-hydrolyzed SBP, respectively (Fig. 5c and d, respectively). The size distribution of isolated CNFs measured from AFM height scans is shown in Supplementary Information Figure S1.

A comparison of the diameter of CNFs in the current work to that in other publications is shown in Table 2. The diameter of CNFs obtained in the current work was among the smallest, and more interestingly, that for the acid hydrolyzed SBP was reached after only one pass through the high-pressure homogenizer. Other studies where similar widths of CNFs were isolated from SBP required many passes through highpressure homogenizers (Agoda-Tandjawa et al. 2012; Pinkl et al. 2017) or the use of many enzymes plus many passes through the homogenizers (Perzon et al. 2020).

\section{Crystallinity}

The XRD patterns of CNFs isolated from acid- and enzyme-hydrolyzed SBP residues are shown in Fig. 6. Both types of CNFs have a cellulose I structure, namely, peaks at $\sim 22^{\circ}$ and $16^{\circ}$, which correspond to diffraction from the (200) and (110) planes, respectively. The calculated degree of crystallinity was higher for CNFs isolated from acid-hydrolyzed SBP ( $\sim 74 \%$ ) compared to that for CNFs isolated from enzyme-hydrolyzed SBP $(\sim 71 \%)$. The higher crystallinity of the acid-hydrolyzed CNFs means that the 
Table 2 Comparison between sizes of CNFs isolated from SBP residue in the current work and in previous publications under the conditions indicated

\begin{tabular}{|c|c|c|c|c|}
\hline Pectin extraction & $\begin{array}{l}\text { Purification } \\
\text { process }\end{array}$ & Fibrillation & Size $(\mathrm{nm})$ & References \\
\hline $\begin{array}{l}\text { Sulfuric acid } \\
\mathrm{pH} 1,85^{\circ} \mathrm{C}, 2 \mathrm{~h}\end{array}$ & $\begin{array}{l}\text { Dilute alkali, } \\
25^{\circ} \mathrm{C} \text {, } \\
\text { bleaching }\end{array}$ & $\begin{array}{l}\text { High-pressure } \\
\text { homogenizer } \\
1 \text { pass }\end{array}$ & $6-10$ & Current work \\
\hline $\begin{array}{l}\text { Xylanase/cellulase enzymes } \\
\mathrm{pH} 5,50^{\circ} \mathrm{C}, 4 \mathrm{~h}\end{array}$ & $\begin{array}{l}\text { Dilute alkali, } \\
25^{\circ} \mathrm{C} \text { bleaching }\end{array}$ & $\begin{array}{l}\text { High-pressure } \\
\text { homogenizer } \\
5 \text { pass }\end{array}$ & $3-5$ & Current work \\
\hline $\begin{array}{l}\text { Alkali treatment } \\
80^{\circ} \mathrm{C}, 2 \mathrm{~h}\end{array}$ & Bleaching & $\begin{array}{l}\text { Microfluidizer } \\
11 \text { pass }\end{array}$ & $20-40$ & $\begin{array}{l}\text { Perzon et al. } \\
\text { (2020) }\end{array}$ \\
\hline Mixture of enzymes & Bleaching & $\begin{array}{l}\text { Microfluidizer } \\
11 \text { pass }\end{array}$ & $\sim 5$ & - \\
\hline $\begin{array}{l}\text { Alkali treatment } \\
80^{\circ} \mathrm{C}, 2 \mathrm{~h} \& \text { mixture of enzymes }\end{array}$ & Bleaching & $\begin{array}{l}\text { Microfluidizer } \\
11 \text { pass }\end{array}$ & $20-40$ & - \\
\hline $\begin{array}{l}\text { Homogenization, } \\
\mathrm{pH} 9,2 \mathrm{~h} \& \text { mixture of six enzymes } 40^{\circ} \mathrm{C} \text { for } \\
24 \mathrm{~h}\end{array}$ & None & $\begin{array}{l}\text { Microfluidizer } \\
18 \mathrm{~min}\end{array}$ & 5 & $\begin{array}{l}\text { Holland et al. } \\
\text { (2019) }\end{array}$ \\
\hline None & Bleaching & $\begin{array}{l}\text { Steam explosion/ultrasonic } \\
\text { treatment }\end{array}$ & $10-50$ & Yang et al. (2018) \\
\hline $\begin{array}{l}\text { Alkali treatment } \\
82^{\circ} \mathrm{C}, 2 \mathrm{~h} \\
\text { None }\end{array}$ & $\begin{array}{l}\text { Bleaching } \\
\text { Bleaching }\end{array}$ & $\begin{array}{l}\text { Microfluidizer } \\
5 \text { passes }\end{array}$ & $\begin{array}{l}\leq 100 \\
\leq 100\end{array}$ & $\begin{array}{l}\text { Hietala et al. } \\
\text { (2017) }\end{array}$ \\
\hline $\begin{array}{l}\text { Alkali treatment, } \\
80^{\circ} \mathrm{C}, 2 \mathrm{~h}\end{array}$ & Bleaching & $\begin{array}{l}\text { High-pressure } \\
\text { homogenizer } \\
20 \text { passes }\end{array}$ & $5-10$ & Pinkl et al. (2017) \\
\hline $\begin{array}{l}\text { Alkali treatment, } \\
80^{\circ} \mathrm{C}, 2 \mathrm{~h}\end{array}$ & Bleaching & $\begin{array}{l}\text { High-pressure } \\
\text { homogenizer } \\
10 \text { passes }\end{array}$ & $10-70$ & Li et al. (2014) \\
\hline $\begin{array}{l}\text { Nitric acid, } 0.1 \mathrm{~N}, 85^{\circ} \mathrm{C}, 30 \mathrm{~min} \text {, repeated } 3 \times \\
\quad \text { Alkali } 80^{\circ} \mathrm{C}, 0.5 \mathrm{~h} \text {, repeated } 3 \times\end{array}$ & None & $\begin{array}{l}\text { Ultrasonication \& } \\
\text { high-pressure } \\
\text { homogenizer } \\
65^{\circ} \mathrm{C} \text { and } 10 \text { passes }\end{array}$ & $2-15$ & $\begin{array}{l}\text { Agoda-Tandjawa } \\
\text { et al. (2010) }\end{array}$ \\
\hline $\begin{array}{l}\text { Alkali treatment } \\
80^{\circ} \mathrm{C}, 2 \mathrm{~h}\end{array}$ & Bleaching & $\begin{array}{l}\text { High-pressure } \\
\text { homogenizer } \\
10-15 \text { passes }\end{array}$ & $30-100$ & $\begin{array}{l}\text { Leitner et al. } \\
\text { (2007) }\end{array}$ \\
\hline $\begin{array}{l}\text { Alkali treatment, } \\
80^{\circ} \mathrm{C}, 2 \mathrm{~h}\end{array}$ & Bleaching & $\begin{array}{l}\text { High-pressure } \\
\text { homogenizer, } 65^{\circ} \mathrm{C} 15 \\
\text { passes }\end{array}$ & $\leq 20^{*}$ & $\begin{array}{l}\text { Dinand et al. } \\
\text { (1999) }\end{array}$ \\
\hline
\end{tabular}

* Estimated from the scale bar on the TEM image since the actual diameter was not mentioned

acid method was more effective in dissolving the amorphous parts of cellulose and hemicelluloses during pectin extraction. This is in accordance with the chemical analysis results mentioned previously. Another peak of low intensity at $2 \theta=8.5-9.0^{\circ}$ appeared in the pattern, which could be assigned to residual pectin (Wathoni et al. 2019); the band was sharper and less broad in case of CNFs isolated from acid-hydrolyzed SBP than that of enzyme-hydrolyzed 


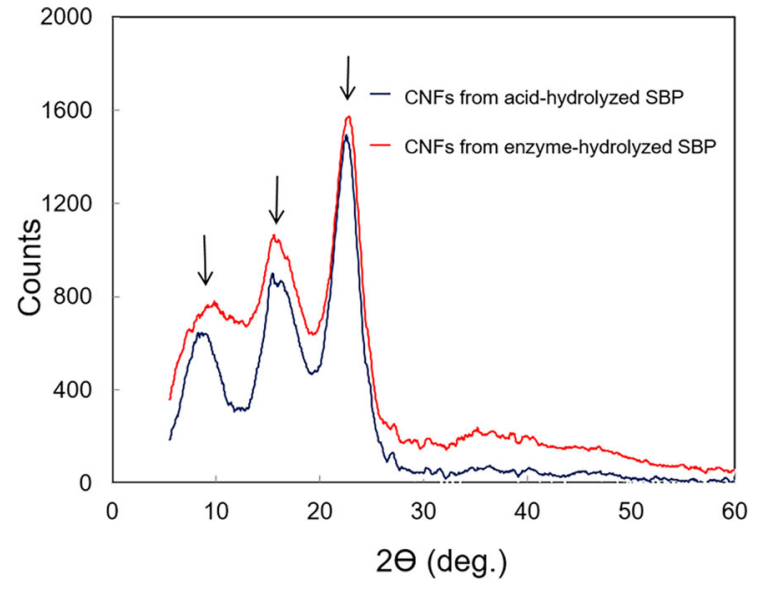

Fig. 6 XRD patterns of CNFs isolated from acid- and enzymehydrolyzed SBP

one, which may indicate different is cyrstallinity of the pectic residues.

\section{Redispersion of freeze-dried CNFs}

The redispersion of dried CNFs is a challenge because of the strong aggregation of the nanofibers by extensive hydrogen bonding upon drying. Previous studies on nanofibers isolated from untreated SBP (without pectin removal) showed the possibility of redispersing the dried nanofibers in water into individual nanofibrils up to $80 \%$ of the dried nanofibers (Hietala et al. 2017). This was attributed to the presence of residual pectin and hemicelluloses attached to the isolated nanofibers. In the current study, redispersion of freezedried CNFs isolated from acid- and enzyme-hydrolyzed SBP was tested using light transmittance measurements (Kangas et al. 2014). Cellulosic nanofibers isolated by chemical-mechanical treatment as in the current work form colloidal suspensions with good transparency because of their nano-dimensions, whereas aggregates of microfiber size are opaque and white. Theoretically, the finer the nanofibers, the higher the transparency of the suspension owing to the higher light transmittance. As shown in Fig. 7, the non-dried CNFs from the acid- and enzyme-hydrolyzed SBP had comparable light transmittance owing to their similar diameters, as shown above in the AFM and TEM images. Upon freeze-drying and redispersion in water, the CNFs isolated from the enzyme-hydrolyzed SBP showed much higher light transmittance than the CNFs isolated from the acid-

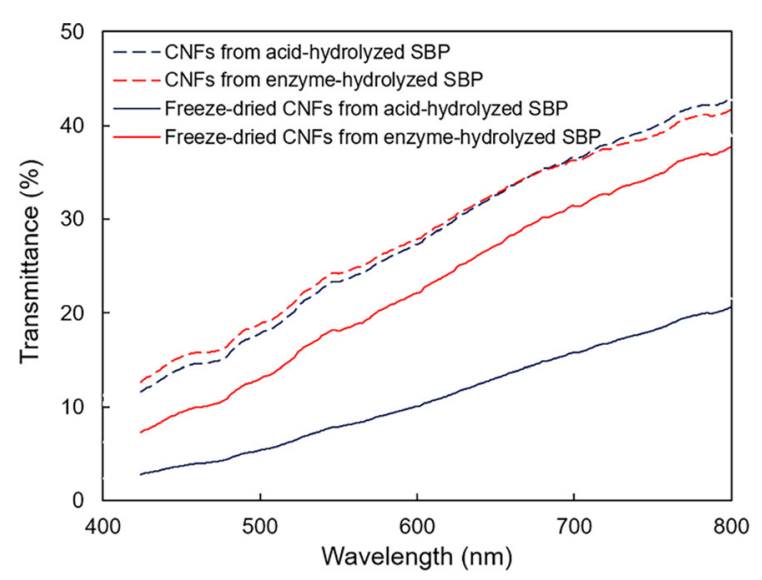

Fig. 7 Light transmittance of $\mathrm{CNF}$ aqueous suspensions before and after freeze-drying and redispersion in water

hydrolyzed SBP, i.e., the CNFs isolated from the enzyme-hydrolyzed SBP showed greater redispersion. This could be attributed to the higher hemicelluloses content and pectin residues in CNFs isolated from the enzyme hydrolyzed SBP.

The presence of these non-cellulosic residues hinders aggregation of the nanofibers upon drying. At $800 \mathrm{~nm}$ (the highest light transmittance obtained), freeze-dried CNFs from enzyme-hydrolyzed SBP retained $90 \%$ light transmittance after redispersion in water as compared to the non-dried CNFs, whereas freeze-dried CNFs isolated from acid-hydrolyzed SBP retained only $51 \%$ light transmittance. The presence of aggregates after redispersion of the CNFs was clearly seen in the optical microscopy images, which show many more aggregates for the redispersed CNFs isolated from acid hydrolyzed SBP (Fig. 8 and Figure S2).

\section{CNF films}

Films made by casting CNF suspensions were prepared and their surface properties were characterized using water contact angle measurements and AFM. Their mechanical properties were also investigated.

\section{Topography and wettability of CNF films}

Figure 9 shows the captured AFM scans, where the root-mean-square roughness was measured from the height images to evaluate and compare any differences of the topographical features. Height and 

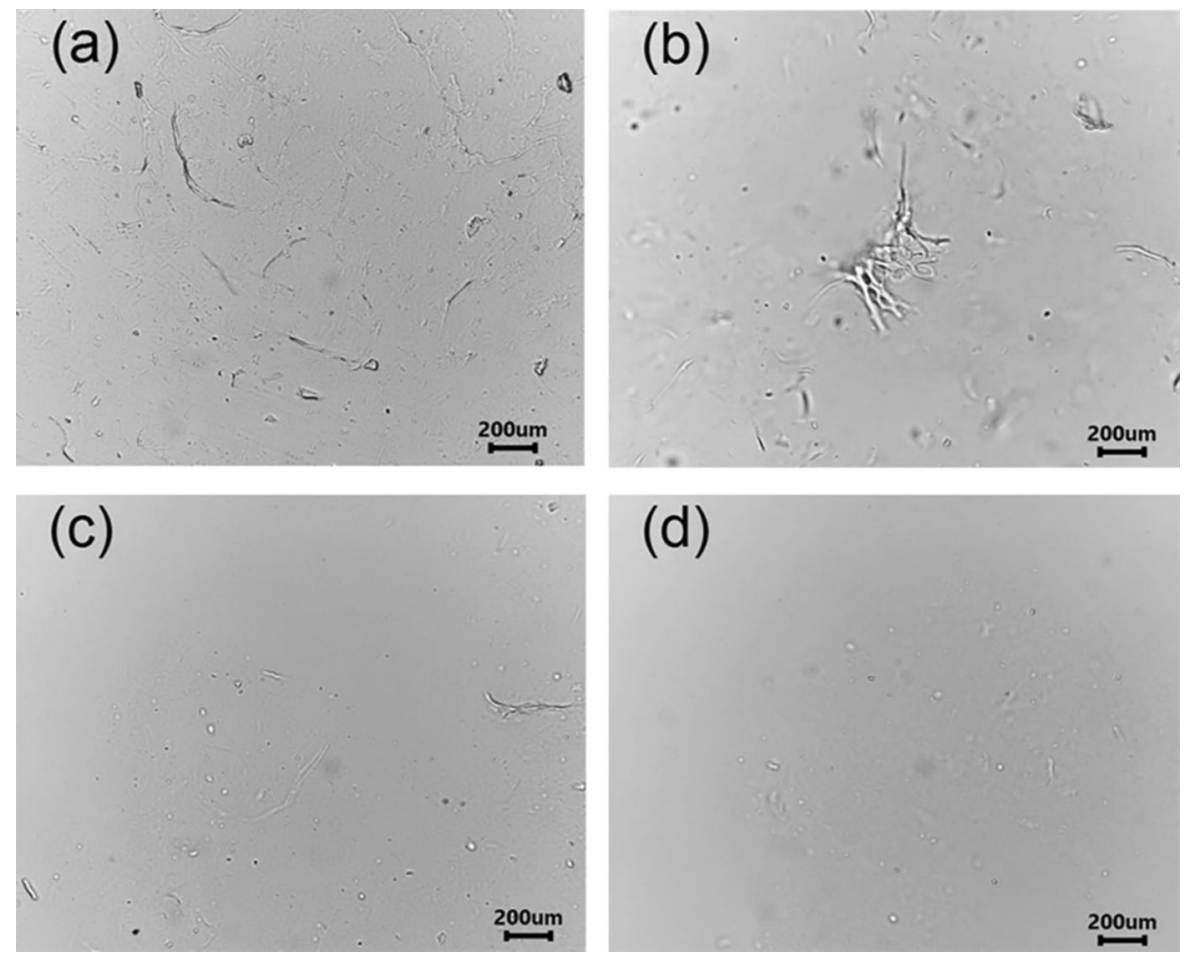

Fig. 8 Optical microscopy images of redispersed CNFs isolated from $\mathbf{a}, \mathbf{b}$ acid-hydrolyzed SBP and $\mathbf{c}, \mathbf{d}$ enzyme-hydrolyzed SBP at two different magnifications
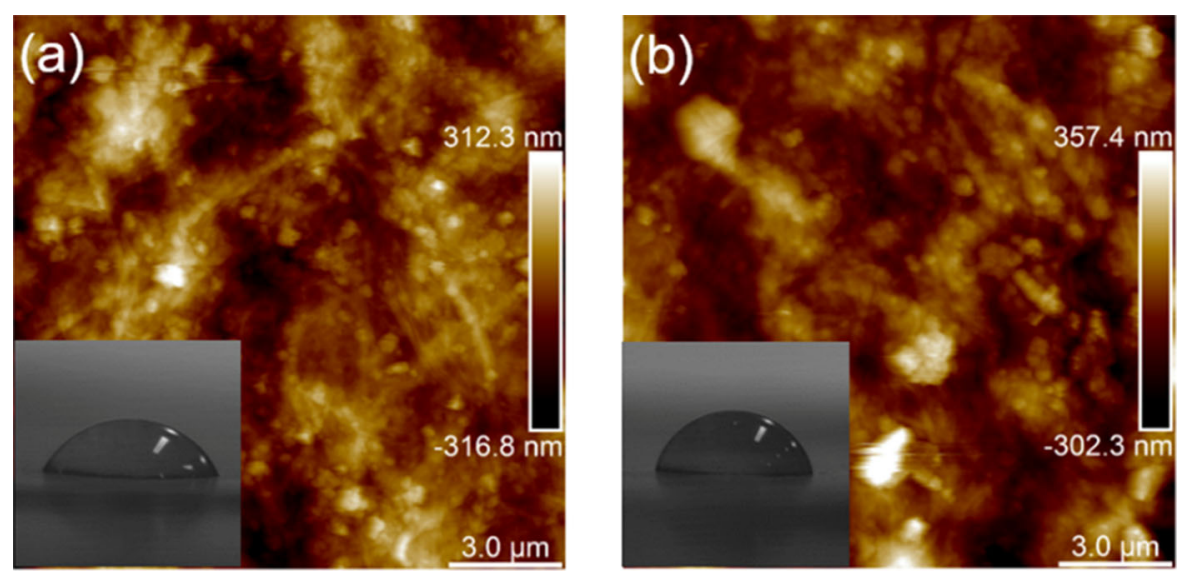

Fig. 9 AFM height image images of CNF films from a acid-hydrolyzed SBP and b enzyme-hydrolyzed SBP. Insets: Photographs of the respective water contact angles

corresponding amplitude AFM images are provided in Supplementary Information Figure S3. Water contact angles are also displayed to compare the wettability behavior of the CNF films from acid- and enzymehydrolyzed SBP.

The CNF films displayed similar surface characteristics, with intertwined yet visually distinguishable nanofibers and spherical particles, as shown in Fig. 9a, b. Their surface roughness, measured from the height scans, were $81 \pm 6 \mathrm{~nm}$ and $76 \pm 6 \mathrm{~nm}$ for CNFs isolated from acid- and enzyme-hydrolyzed SBP, respectively. CNF films isolated from acid-hydrolyzed SBP displayed slightly higher wettability, with a water contact angle of $56^{\circ} \pm 1.9^{\circ}$, whereas that of enzyme- 
hydrolyzed SBP was $61^{\circ} \pm 1.3^{\circ}$ (Fig. 9a, b, insets). It is well known that the water contact angle correlates with the topographical structure of the surface (Herrera et al. 2014). In addition, the wettability of cellulosic surfaces toward water has previously been reported to decrease upon the reduction of hemicelluloses for wood (Hosseinaei et al. 2011) and with the reduction of hemicelluloses and pectin for CNFs from carrot residue (Berglund et al. 2020). In the current work, although CNFs isolated from enzyme-hydrolyzed SBP had more hemicelluloses than those isolated from acid-hydrolyzed SBP, films from the latter had a slightly higher water contact angle. This could be owing to the higher roughness of the surface of the CNF films isolated from the acid hydrolyzed SBP.

\section{Mechanical properties CNF films}

The mechanical properties (maximum tensile strength, Young's modulus, and strain at maximum load) of CNF films prepared from both types of isolated nanofibers were measured. Stress-strain curves for representative samples are shown in Supplementary Information Figure S4. CNF films isolated from acidand enzyme-hydrolyzed SBP had close tensile strength values $(49 \pm 5$ and $52 \pm 6 \mathrm{MPa}$, respectively). Young's modulus was $2.2 \pm 0.6$ and $2.8 \pm 0.7 \mathrm{GPa}$ and strain was $6.7 \pm 0.8 \%$ and $4.3 \pm 0.6 \%$, for nanofibers isolated from acid- and enzyme-hydrolyzed SBP, respectively. This higher Young's modulus could be owing to the higher DP of nanofibers from the enzyme hydrolyzed SBP. The DP values for CNFs isolated from enzyme- and acidhydrolyzed SBP were 639 and 894, respectively. The relatively lower mechanical properties of CNF films in the current study as compared to those reported in previous studies could be attributed to the following reasons. In the current study, acid hydrolysis $(\mathrm{pH}$ adjusted to 1) and cellulases enzymes were used in the extraction of pectin. This have resulted in greater degradation of the cellulose chains than in other studies where alkali treatment was used to remove pectin (Leitner et al. 2007; Hietala et al. 2017; Pinkl et al. 2017; Perzon et al. 2020). Alkali treatment conditions used in the previous studies removed almost all pectin, hemicelluloses, and short-chain cellulose, and thus there was a lower possibility of degrading cellulose than when using acid or cellulase enzymes. In addition, in one of these studies (Hietala et al. 2017), the films from the isolated nanofibers were prepared by hot pressing at elevated temperatures $\left(110{ }^{\circ} \mathrm{C}\right.$ and $11 \mathrm{MPa}$ pressure for $30 \mathrm{~min}$ ), whereas those prepared in the current work were dried without pressure.

\section{Conclusions}

This study has shown that the removal of pectin using sulfuric acid- or xylanase/cellulase enzymatic hydrolysis leads to a residue with a high cellulose content and thus to a suitable raw material for production of CNFs. The progression of CNF isolation from de-pectinated SBP and the width of the isolated CNFs was dependent on the method of extracting pectin. CNFs with homogenous widths similar to those of elementary cellulose fibrils (approximately $5-10 \mathrm{~nm}$ ) from SBP de-pectinated using sulfuric hydrolysis were easily isolated after one pass through a high-pressure homogenizer, whereas five passes were needed for enzyme de-pectinated SBP. Under the conditions used in this study, the extraction of pectin with sulfuric acid removed most of the hemicelluloses and pectin, resulting in easier fibrillation of cellulose fibers than was the case when extracting pectin with enzymes. However, the presence of more residual hemicelluloses for CNFs isolated from enzyme-hydrolyzed SBP resulted in higher redispersion of the freeze-dried nanofibers for CNFs isolated from acid-hydrolyzed SBP. Because of the greater degradation of cellulose during pectin extraction for the acid-hydrolyzed SBP, the prepared films had a lower tensile modulus than those for the enzyme-hydrolyzed SBP. Finally, comparing the mechanical properties of CNF films in the current study to those previously published ones, where pectin was removed mainly by alkali treatment, the extraction of pectin from SBP by industrially practiced mineral acid hydrolysis or by using cellulase enzymes resulted in nanofibers with lower mechanical properties than in the case of using alkali treatment in pectin extraction.

Acknowledgments This research was funded by the Swedish Research Council (Project No. 2015-05847) and received financial support from Bio4Energy, a strategic research environment appointed by the Swedish government; Swedish Foundation for Strategic Research within the HEALiX project (RMX18-0039), Kempe Foundations for the use of AFM, and 
Science and Technology Development Fund (STDF, Egypt, Project No. 25848). The authors also thank Prof. Dr. Aisha M. Moustafa and Prof. Dr. Amal F. Hegab, XRD laboratory, Physics Division, National Research Centre, for their kind help for carrying out the XRD analysis.

Author contributions Conceptualization, $\mathrm{MH}$ and $\mathrm{KO}$; Funding Acquisition, $\mathrm{MH}$ and $\mathrm{KO}$; Investigation, $\mathrm{MH}, \mathrm{LB}$, EH, WSA-E, and KO; Methodology, MH, LB, EH, and WSA-E; Project Administration, $\mathrm{KO}$; Supervision, $\mathrm{MH}$ and $\mathrm{KO}$; Writing-Original Draft, MH; Writing-Review and Editing, MH, KO, LB, EH, WSA-E.

Funding Open access funding provided by Luleå University of Technology.

Availability of materials and data All data generated or analyzed during this study are included in this published article (and its Supplementary Information files).

\section{Declarations}

Conflict of interest The authors declare no competing interests.

Open Access This article is licensed under a Creative Commons Attribution 4.0 International License, which permits use, sharing, adaptation, distribution and reproduction in any medium or format, as long as you give appropriate credit to the original author(s) and the source, provide a link to the Creative Commons licence, and indicate if changes were made. The images or other third party material in this article are included in the article's Creative Commons licence, unless indicated otherwise in a credit line to the material. If material is not included in the article's Creative Commons licence and your intended use is not permitted by statutory regulation or exceeds the permitted use, you will need to obtain permission directly from the copyright holder. To view a copy of this licence, visit http://creativecommons.org/licenses/by/4.0/.

\section{References}

Abou-Elseoud WS, Hassan EA, Hassan ML (2021) Extraction of pectin from sugar beet pulp by enzymatic and ultrasound-assisted treatments. Carbohydr Polym Technol Appl 2:100042

Agoda-Tandjawa G, Durand S, Berot S, Blassel C, Gaillard C, Garnier C, Doublier J-L (2010) Rheological characterization of microfibrillated cellulose suspensions after freezing. Carbohydr Polym 80:677-686

Agoda-Tandjawa G, Durand S, Gaillard C, Garnier C, Doublie JL (2012) Properties of cellulose/pectins composites: implication for structural and mechanical properties of cell wall. Carbohydr Polym 90:1081-1091

Babbar N, Roy VS, Wijnants M, Dejonghe W, Caligiani A, Sforza S, Elst K (2016) Effect of extraction conditions on the saccharide (neutral and acidic) composition of the crude pectic extract from various agro-industrial residues. J Agric Food Chem 64:268-276

Berglund L, Breedveld L, Oksman K (2020) Toward eco-efficient production of natural nanofibers from industrial residue: eco-design and quality assessment. J Clean Prod 255:120274

Browning BL (1967) Methods of wood chemistry, vol II. Wiley, New York, p 489

Combo AM, Aguedo M, Quiévy N, Danthine S, Goffin D, Jacquet N, Blecker C, Devaux J, Paquot M (2013) Characterization of sugar beet pectic-derived oligosaccharides obtained by enzymatic hydrolysis. Int J Biol Macromol 52:148-156

Concha J, Weinstein C, Zúñiga ME (2013) Production of pectic extracts from sugar beet pulp with antiproliferative activity on a breast cancer cell line. Front Chem Sci Eng 7:482-489

Dinand E, Chanzy H, Vignon R (1999) Suspensions of cellulose microfibrils from sugar beet pulp. Food Hydrocolloid 13:275-283

Fischer M, Arrigoni E, Amado R (1994) Changes in the pectic substances of apples during development and postharvest ripening. Part 2: analysis of the pectic fractions. Carbohydr Polym 25:167-175

Fishman ML, Chau HK, Coffin DR, Cooke PH, Qi P, Yadav MP, Hotchkiss AT Jr (2011) Physico-chemical characterization of a cellulosic fraction from sugar beet pulp. Cellulose 18:787-801

Fry SC (1986) Cross-linking of matrix polymers in the growing cell walls of angiosperms. Annu Rev Plant Physiol 37:165-186

Hassan ML, Berglund L, Hassan E, Abou-Zeid R, Oksman K (2018) Effect of xylanase pretreatment of rice straw unbleached soda and neutral sulfite pulps on isolation of nanofibers and their properties. Cellulose 25:2939-2953

Herrera MA, Mathew AP, Oksman K (2014) Gas permeability and selectivity of cellulose nanocrystals films (layers) deposited by spin coating. Carbohydr Polym 112:494-501

Hietala M, Sain S, Oksman K (2017) Highly redispersible sugar beet nanofibers as reinforcement in bionanocomposites. Cellulose 24:2177-2189

Holland C, Perzon A, Cassland PRC, Jensen JP, Langebeck B, Sørensen OB, Whale E, Hepworth D, Plaice-Inglis R, Moestrup Ø, Ulvskov P, Jørgensen B (2019) Nanofibers produced from agro-industrial plant waste using entirely enzymatic pretreatments. Biomacromolecules 20:443-453

Hosseinaei O, Wang SQ, Rials TG, Xing C, Zhang Y (2011) Effect of decreasing carbohydate content on properties of wood strands. Cellulose 18:841-850

Iiyama K, Lam TB-T, Stone BA (1994) Covalent cross-links in the cell wall. Plant Physiol 104:315-320

Kangas H, Lahtinen P, Sneck A, Hellén E, Saariaho A-M, Laitinen O (2014) Characterization of fibrillated celluloses. A short review and evaluation of characteristics with a combination of methods. Nordic Pulp Pap Res J 29:129-143

Kato Y, Kobayashi M (2000) Isolation and characterization of hemicelluloses from beet pulp. J Appl Glycosci 47:45-48

Leitner J, Hinterstoisser B, Wastyn M, Keckes J, Gindl W (2007) Sugar beet cellulose nanofibril-reinforced composites. Cellulose 14:419-425 
Levigne S, Ralet MC, Thibault JF (2002) Characterisation of pectins extracted from fresh sugar beet under different conditions using an experimental design. Carbohydr Polym 49:145-153

Li M, Wang L-J, Li D, Cheng Y-L, Adhikari B (2014) Preparation and characterization of cellulose nanofibers from depectinated sugar beet pulp. Carbohydr Polym 102:136-143

Meseguer I, Aguilar M, González MJ, Martínez C (1998) Extraction and colorimetric quantification of uronic acids of the pectic fraction in fruit and vegetables. J Food Compos Anal 11:285-291

Pacheco MT, Villamiel M, Moreno R, Moreno FJ (2019) Structural and rheological properties of pectins extracted from industrial sugar beet by-products. Molecules 24:392

Perzon A, Jørgensen B, Ulvskov P (2020) Sustainable production of cellulose nanofiber gels and paper from sugar beet waste using enzymatic pre-treatment. Carbohydr Polym 230:115581

Pinkl S, Veige S, Colson J, Gindl-Altmutter W (2017) Nanopaper properties and adhesive performance of microfibrillated cellulose from different ligno-cellulosic raw materials. Polymers 9:326

Sàez-Plaza P, Michałowski T, Navas MJ, Asuero AG, Wybraniec S (2013) An overview of the Kjeldahl method of nitrogen determination. Part I. Early history, chemistry of the procedure, and titrimetric finish. Crit Rev Anal Chem 43:178-223

Schols H, Coenen G, Voragen A (2009) Revealing pectin's structure. In: Schols HA, Visser RGF, Voragen AGJ (eds) Pectins and pectinases. Wageningen Academic Publishers, Wageningen, pp 19-34

Sidiras DK, Koullas DP, Vgenopoulos AG, Koukios EG (1990) Cellulose crystallinity as affected by various technical processes. Cellul Chem Technol 24:09-317

Siew CK, Williams PA (2008) Role of protein and ferulic acid in the emulsification properties of sugar beet pectin. J Agric Food Chem 56:4164-4171

Stevanato P, Chiodi C, Broccanello C, Concheri G, Biancardi E, Pavli O, Skaracis G (2019) Sustainability of the sugar beet crop. Sugar Technol 21:703-716
Thomas B, Raj M, Athira B, Rubiyah H, Joy J, Moores A, Drisko G, Sanchez C (2018) Nanocellulose, a versatile green platform: from biosources to materials and their applications. Chem Rev 118:11575-11625

Vartiainen J, Lahtinen P, Kaljunen T, Kunnari V, Peresin MS, Tammelin T (2015) Comparison of properties between cellulose nanofibrils made from banana, sugar beet, hemp, softwood and hardwood pulps. O PAPEL 76:57-60

Vincken J-P, Schols HA, Oomen RJFJ, McCann MC, Ulvskov P, Voragen AGJ, Visser RGF (2003) If homogalacturonan were a side chain of rhamnogalacturonan I. Implications for cell wall architecture. Plant Physiol 132:1781-1789

Wathoni N, Shan CY, Shan WY, Rostinawati T, Indradi RB, Pratiwi R, Muchtaridi M (2019) Characterization and antioxidant activity of pectin from Indonesian mangosteen (Garcinia mangostana L.) rind. Heliyon 5:e02299

Wise LE, Murphy M, D’Addieco AA (1946) Chlorite holocellulose. Its fractionation and bearing on summative wood analysis and on studies on the hemicelluloses. TAPPI 29:210-218

Yang W, Feng Y, He H, Yang Z (2018) Environmentallyfriendly extraction of cellulose nanofibers from steam-explosion pretreated sugar beet pulp. Materials 11:1160

Zykwinska AW, Ralet MC, Garnier CD, Thibault JF (2005) Evidence for in vitro binding of pectin side chains to cellulose. Plant Physiol 139:397-407

Zykwinska A, Thibault J-F, Ralet M-C (2007) Organization of pectic arabinan and galactan side chains in association with cellulose microfibrils in primary cell walls and related models envisaged. J Exp Bot 58:1795-1802

Zykwinska A, Boiffard M-H, Kontkanen H, Buchert J, Thibault J-F, Bonin E (2008) Extraction of green labelled pectins and pectic oligosaccharides from plant byproducts. J Agric Food Chem 56:8926-8935

Publisher's Note Springer Nature remains neutral with regard to jurisdictional claims in published maps and institutional affiliations. 